Tabligh: Jurnal Komunikasi dan Penyiaran Islam

Volume 1, Nomor 2 (2016) 19-36

Fakultas Dakwah dan Komunikasi, UIN Sunan Gunung Djati Bandung https://jurnal.fdk.uinsgd.ac.id/index.php/tabligh

\title{
Dakwah Majelis Rasulullah dan Kecintaan Jama'ah kepada Dakwah Islam
}

\author{
Anisatul Ikrima*, Karsidi Diningrat, \& Rojudin \\ Jurusan Komunikasi dan Penyiaran Islam, Fakultas Dakwah dan Komunikasi, \\ UIN Sunan Gunung Djati, Bandung \\ *Email: ikrima.anisa@gmail.com
}

\begin{abstract}
ABSTRAK
Penelitian ini mengungkapkan dakwah Islam yang dilakukan oleh Majelis Rasulullah Tambun Cibitung Cikarang, kecintaan jama'ah terhadap dakwah Islam, dan pengaruh dakwah Islam yang dilakukan Majelis Rasulullah Tambun Cibitung Cikarang terhadap kecintaan jama'ah. Metode Penelitian menggunakan analisis kuantitatif. Hasil penelitian menunjukkan jumlah variabel X mencapai 46,4. Setelah dibagi jumlah item diperoleh angka 4,64 dan jumlah Variabel Y mencapai 47,36. Setelah dibagi oleh jumlah item diperoleh angka 4,736. Kedua variabel ini memiliki kualifikasi sangat tinggi karena berada pada interval 4,20-5,00. Koefisien kolerasi sebesar 1,0. Nilai koefisien korelasi pada penelitian ini berada pada interval 0,81-1,00 yang dinyatakan korelasi sempurna. Pengaruh Majelis Rasulullah, koefisiennya 1,0 dengan kadar pengaruhnya 40\% hal tersebut dapat disimpulkan bahwa masih ada sekitar 60\% dari faktor lain yang turut mempengaruhi terhadap kecintaan jama'ahnya dalam dakwah Islam.
\end{abstract}

Kata Kunci : Jama'ah; Dakwah Islam; Majelis Rasulullah.

\begin{abstract}
This research discusses the Islamic proselytizing conducted by Majelis Rasulullah Tambun Cibitung Cikarang, the congregations love of the forum toward Islamic proselytizing, and the influence of Islamic proselytizing conducted by Majelis Rasulullah Tambun Cibitung Cikarang on the congregations of the forum's love. The result showing the amount of $X$ variable reach 46,4. After divided by the number of items obtained the number 4,64 and the amount of $Y$ variable reach 47,36. After divided by the number of items obtained the number 4,736. The both of this variable has very high qualification because at interval 4,20-5,00. The correlation coefficient is 1,0. The value of correlation
\end{abstract}


A. Ikrima, K. Diningrat, \& Rojudin

coefficient in this research was at the interval 0,81-1.00 which expressed perfect correlation. The influence Majelis Rasulullah, has coefficient 1,0 with 40\% level of influence, it can be concluded that there are still around 60\% from other factor which also influence to follower's love in Islamic proselytizing.

Keyword: Congregations; Islamic Proselytizing; Majelis Rasulullah.

\section{PENDAHULUAN}

Setiap manusia yang bersungguh-sungguh untuk berubah menjadi baik dan selalu memohon pertolongan Allah Swt, tentu ia akan dimudahkan olehNya. Mendengarkan ceramah agama, memikirkan ciptaan Allah Swt, membina dan melatih jiwa, berkumpul dengan orang-orang shaleh, senantiasa berdo'a dan melakukan kebaikan adalah salah satu cara mendapatkan pertolongan Allah Swt. Allah Swt telah menentukan dua jalan yaitu jalan yang benar dan jalan yang sesat atau salah. Allah memerintahkan untuk berada dan mengikuti jalan yang benar dan sangat melarang berada dan mengikuti jalan yang sesat atau salah.

Dakwah hanya mengubah pemahaman yang salah kepada pemahaman yang benar. Dan dakwah juga mewujudkan perubahan dari lingkungan yang salah dan lingkungan yang benar. Setelah itu, mad'u sesudah memahami pesan dakwah maka diberi kebebasan untuk mengikuti Islam atau meninggalkannya. Da'i mendorong para mad'u melalui kreasi pesan dakwah (al-da'wah bi al-maqal wa al-kitabab) dan melalui kreasi lingkungan (al-da'wab bi al-hal). (Aziz, 2009: 127)

Cinta adalah fitrah manusia. Sepatutnya ia selalu mengajak pada yang baik. Tetapi, banyak dari mereka yang salah dalam memahami cinta. Jadi mana cinta yang sebenarnya ? Mana cinta yang lebih utama? Pantas tidak cinta kita pada seseorang disamakan dengan cinta kepada Allah Swt ? Cinta yang seperti apa yang membuat hidup bahagia? dan cinta yang seperti apa yang membuat sengsara? Ibnul Qayim membagi cinta ke dalam 5 jenis yang diringkas menjadi 3. Yaitu: Mahabbatullah wa Mababbatu ma yubibbullah, Al-Hubbu Fillah wa lillah, Al-Mahabbah ma'allah dan Mababbah ath-Thabi'iyah. (Nesia, 2015: 7)

Mahabbatullah wa Mababbatu ma yubibbullab (cinta kepada Allah Swt). Cinta jenis ini ditujukan kepada Allah Swt. Maha pemilik cintalah objek yang kita cinta. Inilah cinta yang sesungguhnya. Tak ada yang menyamai kemuliaan cinta ini. Memang pantas bukan kita mencintai sang pemberi cinta dan yang memiliki cinta. Sungguh bahagia seorang yang memiliki jenis 
ini karena tidak mudah menumbuhkan cinta yang mulia dari hati kita, ruh suci kita sendiri yag menumbuhkannya. Ketika kita telah mencitai sesuatu kita akan mencintai apa yang sesuatu itu cinta. CintaNya adalah cintaku. KeinginanNya adalah keinginanku.

Al-Hubbu Fillah wa lillah (kecintan di jalan Allah dan karena Allah). Cinta jenis ini adalah jenis cinta yang biasa dimiliki oleh banyak manusia. Contohnya: cinta sang lelaki kepada kekasih perempuannya karena Allah. Cinta sesama karena Allah. Karena Allah lah mereka saling mencintai, saling memamhami. Sehingga tidak ada niat kufur, maksiat dan lainnya. Inilah dua jenis cinta yang harus ditumbuhkan didalam hati. Cinta yang membuat bahagia dan jikalau air mata hingga menetes bukan karena rasa kekecewaan atau rasa sakit melainkan rasa cinta kita kepada Allah Swt.

Habib Munzir Al-Musawa mulai berdakwah dengan mengunjungi rumah-rumah, duduk dan bercengkerama dengan mereka, mengajarkan Fiqh dasar, namun tampak ummat kurang bersemangat menerima bimbingannya, Habib munzir terus mencari sebab agar masyarakat ini asyik kepada kedamaian, meninggalkan kemungkaran dan mencintai sunnah sang Nabi saw, maka Habib Munzir merubah penyampaiannya.

Ia tidak lagi membahas permasalahan Fiqih dan kerumitannya, melainkan mewarnai bimbingannya dengan nasehat-nasehat mulia dari Hadits-hadits Rasul saw dan ayat Alqur'an dengan Amr Ma'ruf Nahi Munkar, dan lalu beliau memperlengkap penyampaiannya dengan bahasa Sastra yang dipadu dengan kelembutan ilahi dan tafakkur penciptaan alam semesta, memberi mereka jalan keluar dalam segala permasalahan.

Ia terus berdakwah dengan meyebarkan kelembutan Allah swt, yang membuat hati pendengar sejuk, tidak mencampuri urusan politik, dan selalu mengajarkan tujuan utama kita diciptakan adalah untuk beribadah kepada Allah swt dan kesemuanya diarahkan agar masyarakat menjadikan Rasulullah SAW sebagai idola. (www.majelisrasulullah.org)

Ketika usia remaja lainnya melakukan hal yang kurang positif. Lain lagi dengan mereka para pemuda dan pemudi yang meluangkan waktunya untuk kegiatan yang positif dan memupuk tali silaturahmi kepada sesama kaum muslim lainnya dengan mengikuti kajian rutin di majelis ini. Salah satu fenomena menarik untuk diteliti di majelis ini jama'ahnya terdiri dari berbagai usia baik dari kalangan orang tua maupun pemuda dan pemudi, namun ketika dibandingkan, jama'ah lebih didominasi oleh para remaja atau pemuda dan pemudi, karena mereka tertarik terhadap nilai-nilai Islam yang sangat positif dan keingintahuan mereka terhadap Nabi Muhammad 


\section{A. Ikrima, K. Diningrat, \& Rojudin}

Saw yang seringkali ditanamkan dalam setiap ceramah ataupun kajian kitab di Majelis ini. Jamaah pemuda dan pemudi umumya mereka adalah para remaja yang masih didunia pendidikan maupun sudah bekerja.

Sejatinya para remaja adalah makhluk yang berada pada posisi dimana cinta yang diserahkan hanya untuk kepada sesama jenis, pergaulan yang tidak jelas, nongkrong dengan teman, tetapi beda dengan mereka para remaja yang ikut serta dalam kegiatan Majelis Rasulullah Tambun Cibitung Cikarang, menyerahkan kecintaannya terhadap Nabi Muhammad Saw yang diambil dari ibrah dalam mengikuti kajian, seni dan ilmu social yang direalisasikan dilingkungan masyarakat sekitar.

Dengan dakwah yang disampaikan secara tegas, jelas dan lantang membuat para remaja tersebut ingin lebih tau secara mendalam apa yang disampaikan lalu dikaji sedemikian mudah untuk direalisasikan. Selain itu dakwah di dalam Majelis Rasulullah Saw disampaikan dengan cara disyairkan melalui music kesenian hadroh. Cerita atau isi dakwah akan dikemas sedemikian unik dalam lantunan syair sehingga menarik para remaja untuk mendengarkan secara khidmat dan mengetahui dengan cara yang tidak membosankan.

Tidak hanya itu saja dakwah yang disampaikan dalam kajian, mereka juga merealisasikan dakwahnya dengan berdagang Karena mereka mencontoh apa yang dilakukan Nabi Muhammad Saw sewaktu menyebarkan agama Islam. Berjiwa sosial pun mereka pupuk untuk mempererat tali silaturahmi dan merasakan apa yang orang lain rasakan, dan berperan penting dalam merubah akhlak para remaja dan masyarakat awam.

Inilah Majelis Rasulullah Saw yang pembimbingannya dengan nasehat-nasehat mulia dari Hadits-hadits Rasul saw dan ayat Alqur'an dengan Amr Ma'ruf Nahi Munkar, dan lalu memperlengkap penyampaiannya dengan bahasa Sastra yang dipadu dengan kelembutan ilahi dan tafakkur penciptaan alam semesta, memberi mereka jalan keluar dalam segala permasalahan, terus berdakwah dengan meyebarkan kelembutan Allah swt, yang membuat hati pendengar sejuk, tidak mencampuri urusan politik, dan selalu mengajarkan tujuan utama kita diciptakan adalah untuk beribadah kepada Allah swt dan kesemuanya di arahkan agar masyarakat menjadikan Rasulullah SAW sebagai idola.

Penelitian ini mengungkapkan bagaimana dakwah Islam yang dilakukan oleh Majelis Rasulullah Tambun Cibitung Cikarang, bagaimana kecintaan jama'ah terhadap dakwah Islam, dan bagaimana pengaruh 
dakwah Islam yang dilakukan Majelis Rasulullah Tambun Cibitung Cikarang terhadap kecintaan jama'ah. Metode Penelitian menggunakan analisis kuantitatif dengan pengumpulan data melalui observasi dan kuisioner.

\section{LANDASAN TEORITIS}

Teori yang dijadikan landasan dalam penelitian ini adalah teori dakwah, metode dakwah dan cinta serta bagian bagian cinta kepada Allah dan Nabi Muhammad Saw. Dakwah dalam implementasinya, merupakan kerja dan karya besar manusia - baik secara personal maupun individual - yang dipersembahkan untuk Tuhan dan sesamanya adalah kerja sadar dalam menegakkan keadilan, meningkatkan kesejahteraan, menyuburkan persamaan, dan mencapai kebahagiaan atas dasar ridla Allah SWT. Dengan demikian, baik secara teologis maupun secara sosiologis dakwah akan tetap ada selama Islam masih menjadi agama manusia. (Enjang dan Aliyudin, 2009: 1)

Secara teologis, dakwah merupakan bagian dari tugas suci (ibadah) umat Islam. Kemudian secara sosiologis, kegiatan dakwah apapun bentuknya dan konteksnya akan dibutuhkan oleh umat manusia dalam rangka menumbuhkan dan mewujudkan keshalehan individual dan keshallehan sosial, yaitu pribadi yang memiliki kasih sayang terhadap sesamanya dan mewujudkan tatanan masyarakat marhamah yang dilandasi oleh kebenaran tauhid, persamaan derajat, semangat persaudaraan, kesadaran akan arti penting kesejahteraan bersama, dan penegakkan keadilan di tengah-tengah kehidupan masyarakat.

Berdasarkan beberapa alasan diatas, maka dakwah memiliki makna dan arti yang begitu penting bagi kehidupan umat manusia. Oleh sebab itu cukup beralasan jika dibutuhkan pemaknaan dan pemahaman baru terhadap dakwah. Apalagi jika didasarkan pada kenyataan masih banyaknya pemahaman masyarkat mengenai dakwah - baik dikalangan alim apalagi dikalangan masyarkat awam - yang masih mengindentikkan dakwah sebagai tabligh atau khitabah.

Dalam kehidupan sehari-hari, khususnya dalam tata pergaulan umat Islam, kata dakwah tentunya bukanlah barang baru, sebab dakwah merupakan salah satu diantara kata yang begitu familier di telinga mereka. Cuma, untuk memahami dakwah lebih komprehensif tentunya diperlukan kajian yang lebih mendalam. Untuk memahami makna dakwah, kita dapat menempuhnya melalui beberapa pendekatan, diantaranya: pendekatan 
A. Ikrima, K. Diningrat, \& Rojudin

bahasa (etimologi) dan istilah (terminolog $\imath$ ), serta kajian filosofis.

Dakwah, secara bahasa (etimologi) merupakan sebuah kata dari bahasa Arab dalam bentuk masdar. Kata dakwah berasal dari kata: دعا- يدعو - دعوة (da'a, yad'u, da'watan) yang berarti seruan, panggilan, undangan atau do'a. Menurut Abdul Aziz, secara etimologis kata dakwah berarti: Memanggil; Menyeru; Menegaskan atau membela sesuatu; Perbuatan atau perkataan untuk menarik manusia kepada sesuatu; dan Memohon dan meminta, atau do'a. Artinya, proses penyampaian pesan-pesan tertentu berupa ajakan, seruan, undangan, untuk mengikuti pesan tersebut atau menyeru dengan tujuan untuk mendorong seseorang upaya melakukan cita-cita tertentu. Oleh karena itu, dalam kegiatannya ada proses mengajak, maka orang yang mengajak disebut da'i dan orang yang diajak disebut mad'u. Dalam firman Allah Swt Qs. AN-Nahl ayat 125:

Serulah (manusia) kepada jalan Tuhan-mu dengan hikmah dan pelajaran yang baik dan bantahlah mereka dengan cara yang baik. Sesungguhnya Tuhanmu Dialah yang lebih mengetahui tentang siapa yang tersesat dari jalan-Nya dan Dialah yang lebih mengetahui orangorang yang mendapat petunjuk. (Depag, 2009: 281)

Berdasarkan ayat-ayat diatas, dapat dipahami bahwa dakwah adalah mengajak manusia kepada jalan Allah (sistem Islam) secara menyeluruh; baik dengan lisan, tulisan, maupun dengan perbuatan sebagai ikhtiar (upaya) muslim mewujudkan nilai-nilai ajaran Islam dalam realitas kehidupan pribadi (syabsiyah), keluarga (usrah) dan masyarakat (jama"ah) dalam semua segi kehidupan secara menyeluruh sehingga terwujud khairul ummah (masyarakat madani).

Katakanlah: "Jika kamu (benar-benar) mencintai Allah, ikutilah Aku, niscaya Allah mengasihi dan mengampuni dosa-dosamu." Allah Maha Pengampun lagi Maha Penyayang. QS. Ali-Imran ayat 31 (Depag, 2009: 54)

Ayat ini sebagai pemutus hukum bagi setiap orang yang mengaku mencintai Allah tetapi tidak menempuh jalan Muhammad, Rasulullah, bahwa dia adalah pembohong dalam pengakuan cintanya itu sehingga dia mengikuti syari'at dan agama yang dibawa oleh Nabi Muhammad dalam semua ucapan dan perbuatannya. Sebagaimana yang disebutkan dalam sebuah hadits shahih, dari Rasulullah, beliau bersabda: "Barang siapa melakukan suatu amal yang tidak ada perintahnya dari kami, maka amalan itu tertolak." (Ghazali, tt: 48)

Cinta tidak pernah habis menjadi buah bibir manusia. Ia selalu hadir 
di relung-relung hati manusia dan menghiasi hari-hari kehidupan mereka di dunia. Jika mereka berkumpul, niscaya pembicaraan yang paling hangat diantara mereka adalah cinta. Dalam perjalanan hidup manusia, kebanyakan pengalaman terindahnya adalah cinta. Cinta ada dalam setiap aspek kehidupan manusia, hingga menembus petala mimpi-mimpi mereka. Dengan cinta mereka berjuang bertahan hidup, menangis, dan tertawa. Adakalanya cinta membuat hidup mereka lurus, bahagia, dan berakhir indah. Namun, cinta terkadang justru membuat hidup mereka tersesat, menderita dan berakhir pada kehancuran. Ahmad (2009: 19)

Cinta manusia dapat hidup lebih tua dari usia mereka dan bahkan bisa menjadi abadi bila ditorehkan dengan tinta sejarah dan disapu warna indah sastra. Legenda Laila dan Qais Majnun di tanah Arab, Roro Mendut dan Prono Citro di tanah Jawa, atau Edward dan Wallis Simpson di Inggris, akan terus hidup hingga akhir zaman. Kisah cinta mereka hidup melampaui batas usia para pelakonnya. Namun, kebanyakan manusia tidak mampu mendefinisikan cinta. Ia, cinta memang sangat mudah mencengkram hati, indah dirasakan, tetapi sangat sulit dikatakan. Ada juga yang keliru mendefinisikannya atau mencampur adukkan cinta, kasih sayang, hawa nafsu, rindu, dan persahabatan. Meskipun demikian, tetap ada upaya untuk mendefinisikannya dan membedakan berbagai peristilahan yang mengiringinya.

Akan tetapi seorang ulama tasawuf, Imam al-Junaid berkata, "Allah mengharamkan cinta terhadap orang yang masih bergantung kepada selainNya". Ia berkata, "setiap cinta yang ditopang dengan imbalan akan sirna jika imbalannya itu sirna". Maka cinta sejati adalah cinta yang memang benar-benar tulus diperjuangkan dan ditegakkan semata-mata tanpa ada embel-embel dibelakangnya. Tulus dan total kepada yang dicintai. Rabiah al-Adawiyah pernah ditanya tentang cintanya kepada Nabi, ia lantas menjawab, "Demi Allah, aku sangat mencintai Nabi, hanya saja Cintaku pada Allah menyibukkan diriku dari mencintai makhluk. "Sementara Nabi Isa a.s, pernah ditanya tentang amal yang paling utama, beliau menjawab, "Amal paling utama adalah, ridha Allah dan mencintai-Nya". (Gazali, 2014: viii)

Dalam pandangan K.H. Abdullah Gymnastiar, jamaah adalah sahabat dan memberi simpati kepadanya sehingga mereka sangat berharga bagi dunia dakwah. Karena itu, keberadaan jama'ah sangat diperhatikan di mana mereka yang datang dilayani dengan baik. Dengan adanya jama'ah maka berarti rezeki. Mereka adalah saudara seiman dan para sahabat yang 


\section{A. Ikrima, K. Diningrat, \& Rojudin}

baik serta ramah yang akan menangkat syiar Islam. Jamaah adalah masyarakat luas yang mengenal Islam pada tahapan awal yang sederhana, baik fahamnya maupun cara berpikinnya. (Bambang Saiful Ma'arif, 2016: 83)

\section{HASIL DAN PEMBAHASAN}

Nama "Majelis Rasulullah." dalam aktifitas dakwah ini berawal ketika Habib Munzir Almusawa lulus dari Studynya di Darul Mustafa pimpinan Al Allamah Al Habib Umar bin Hafidh Tarim Hadramaut, Yaman. Beliau kembali ke Jakarta dan memulai berdakwah pada tahun 1998 dengan mengajak orang bertobat dan mencintai Nabi Saw sehingga umat Islam akan pula mencintai sunnahnya, dan menjadikan Rasul Saw sebagai Idola.

Habib Munzir mulai berdakwah siang dan malam dari rumah kerumah di Jakarta, ia tidur dimana saja dirumah-rumah masyarakat, bahkan pernah ia tertidur di teras rumah orang karena penghuni rumah sudah tidur dan ia tak mau membangunkan mereka di larut malam. Setelah berjalan kurang lebih enam bulan, Habib Munzir memulai membuka Majelis setiap malam selasa (mengikuti jejak gurunya Al Habib Umar bin Hafidz yang membuka Majelis minggu-an setiap malam selasa), dan ia pun memimpin Ma'had Assa'adah, yang di wakafkan oleh Al Habib Umar bin Hud Alattas di Cipayung, setelah setahun, munzir tidak lagi meneruskan memimpin ma'had tersebut dan melanjutkan dakwahnya dengan menggalang majelis-majelis di seputar Jakarta.

Habib Munzir membuka majelis malam selasa dari rumah kerumah, mengajarkan Fiqh dasar, namun tampak ummat kurang bersemangat menerima bimbingannya, dan Habib munzir terus mencari sebab agar masyarakat ini asyik kepada kedamaian, meninggalkan kemungkaran dan mencintai sunnah sang Nabi saw, maka Habib Munzir merubah penyampaiannya, ia tidak lagi membahas permasalahan Fiqih dan kerumitannya, melainkan mewarnai bimbingannya dengan nasehat-nasehat mulia dari Hadits-hadits Rasul saw dan ayat Alqur'an dengan Amr Ma'ruf Nahi Munkar, dan lalu beliau memperlengkap penyampaiannya dengan bahasa Sastra yang dipadu dengan kelembutan ilahi dan tafakkur penciptaan alam semesta, yang kesemuanya di arahkan agar masyarakat menjadikan Rasul saw sebagai idola, maka pengunjung semakin padat hingga ia memindahkan Majelis dari Musholla ke musholla, lalu Musholla pun tak mampu menampung hadirin yang semakin padat, maka Habib Munzir memindahkan Majelisnya dari Masjid ke Masjid secara bergantian. 
Mulailah timbul permintaan agar Majelis ini diberi nama, Habib Munzir dengan polos menjawab, "Majelis Rasulullah?", karena memang tak ada yang dibicarakan selain ajaran Rasul saw dan membimbing mereka untuk mencintai Allah dan Rasul Nya, dan pada dasarnya semua Majelis taklim adalah Majelis Rasulullah saw. Majelis kian memadat, maka Munzir mengambil empat masjid besar yang bergantian setiap malam selasa, yaitu masjid Raya Almunawar Pancoran Jakarta Selatan, Masjid Raya At Taqwa Pasar minggu Jakarta Selatan, Masjid Raya At Taubah Rawa Jati Jakarta Selatan, dan Ma had Daarul Ishlah Pimp. KH. Amir Hamzah di Jalan Raya Buncit Kalibata Pulo, Namun karena hadirin semakin bertambah, maka Habib Munzir akhirnya memusatkan Majelis Malam selasa ini di Masjid Raya Almunawar Pancoran Jakarta Selatan, kini acara ini dihadiri berkisar antara 10.000 hadirin setiap minggunya.

Habib Munzir juga meluaskan wilayah da'wah di beberapa wilayah Jakarta dan Sekitarnya, lalu mencapai hampir seluruh wilayah Pulau Jawa, Majelis Rasulullah tersebar di sepanjang Pantai Utara Pulau jawa dan Pantai Selatan, dan terus makin meluas ke Bali, Mataram, Irian Barat, bahkan Singapura, Johor dan Kualalumpur, demikian pula di stasion stasion TV Swasta, bahkan VCD, Majalah bulanan dll, dan kini Anugerah ilahi telah merestui Majelis Rasulullah untuk meluas ke Jaringan internet dengan nama asalnya "Website Majelis Rasulullah". (www.majelisrasulullah.org)

\section{Kegiatan Dakwah Majelis Rasulullah Tambun Cibitung Cikarang}

"Majelis Rasulullah TCC" adalah kependekan dari "Jamaah Majelis Rasulullah SAW wilayah Tambun, Cibitung, Cikarang" merupakan forum silaturahim atau media pemersatu jamaah MR yang tinggal di wilayah Kabupaten Bekasi dan sekitar, terdiri dari kaum anshor (warga asli) \& mubajirin (warga pendatang). Forum silaturrahim ini terencana pada pertengahan tahun 2009 mulai dari sebuah rencana pribadi ketika diawali perkenalan dan berangkat rutinan di Majelis Rasulullah pusat, perasaan sedih tatkala ada satu atau dua orang yang memakai identitas Majelis Rasulullah tetapi tidak saling mengenal dan mulailah perkenalan dengan seorang jama'ah yang bernama Indra, hanya dengan berdua lah kami mencari jama'ah yang mulai mencari di jalan raya yang sampai memberhentikan pengendara motor dan dimintai nomer telephon untuk menyambung tali silaturahim dan mengundangnya ketika setiap diadakannya pengajian. 
Dari mulai tekad dan niat ingin mempererat tali silaturahim dan membentuk jama'ah maka mulailah pada tanggal 10 Juli 2010 resmi didirikan forum silaturrahim ini, pada awalnya nama majelis ini adalah MRCCT tetapi berjalannya waktu dan kesepakatan nama tersebut diganti menjadi MRTCC (Majelis Rasulullah Tambun Cibitung Cikarang). Pada awalnya kegiatan ini diadakan dari rumah ke rumah yang dihadiri oleh para habaib, ulama, ustadz, jama'ah dan warga sekitar. Kemudian ada salah seorang mahasiswa yang aktif dan menguasai teknologi maka disebarlah nama majelis rasulullah ini melalui duia maya dan alhamdulillah dengan perkembangan melalui informasi dunia maya maka berkembanglah majelis ini dengan ribuan jama'ah, dan melalui kegiatan "Konvoi sepeda motor" untuk menghadiri acara akbar Majelis Rasulullah SAW dan pengajian rutinan.

Dengan niat tulus dalam rangka membantu syiar da'wah yang di emban Majelis Rasulullah SAW maka Jamaah MR TCC turut menyemarakkan da'wah di wilayah Bekasi \& sekitar, serta berupaya menghadirkan da'wah Majelis Rasulullah SAW di wilayah Kabupaten Bekasi. Semoga Allah ta'ala senantiasa ridho atas upaya kami ini dan menjadikan washilah turunnya limpahan rahmat dari Allah ta'ala di wilayah Bekasi dan sekitar, serta tujuan lain mendirikan Majelis Rasulullah TCC ini menjadi benteng bagi kaum muslimin, muslimat dari kerusakan moral dan kesesatan aqidah dan sebuah tujuan atau niat utama hanya ingin membuat Rasulullah SAW tersenyum bahagia \& Guru mulia Habibana Munzir bangga. (Erwin, wawancara: 2016)

Untuk mengetahui seberapa pengaruhnya Dakwah Majelis Rasulullah Hubungannya dengan Jama'ahnya, menunjukkan hasil penjelasan dari indikator tanggapan jama'ah terhadap dakwah MRTCC, meliputi: Tujuan

berdakwah, Pesan Dakwah, Kriteria Seorang Da'i, Persiapan Dakwah, Media Dakwah, Kewajiban Dakwah.

\section{Faktor Pendukung dan Penghambat Kegiatan Majelis Rasulullah Tambun Cibitung Cikarang Kabupaten Bekasi.}

Selain faktor pendukung untuk kegiatan dakwah ini juga ada faktor penghambatnya. Faktor penghambatnya yaitu dimana motivasi dan keinginan dalam diri sendiri enggan untuk mengenal dan mencintai Rasulullah. Walaupun informasi dakwah atau segala sesuatu mengenai Rasulullah baik di dunia maya maupun media tulis lainnya jika kurangnya 
kesadaran dan motivasi untuk mengenal lalu mencintai maka ia akan tetap pada posisi pada ketidak tahuan dan kurang mencintai.

"Pesan untuk generasi selanjutnya, tanamkan pada diri kalian sebuah kesadaran dan keingin tahuan untuk mengenal Rasulullah setelah mengenal maka akan timbul rasa cinta untuk Rasulullah. Rasulullah shallallohu 'alaihi wa sallam adalah orang yang paling utama untuk kita cintai. Bahkan, lebih diutamakan dari kecintaan kita terhadap diri kita sendiri. Dengan mencintai Rasulullah maka kita akan merasakan manisnya keimanan. Bahwasanya agama Allah mengajak kita untuk saling menyayangi, mengajak kita untuk keselamatan, untuk mengajak kita saling menyayangi, dengan itu baginda nabi Muhammad Saw mengatakan perumpamaan kasih sayang dan kelembutan di antara muslimin seperti satu jasad, jika satu anggota jasad tersebut terluka maka seluruh anggota tersebut merasakan panas, dan sakit" (Erwin, Wawancara; 2016).

\section{Pengaruh Dakwah Majelis Rasulullah Tambun Cibitung Cikarang}

Selain pengajian dan kajian kitab, MRTCC ini melakukan dakwah juga dengan berdagang atau berwirausaha karena mengikuti jejak Nabi Muhammad yang mensyiarkan agama melalui perdagangan. Selain itu juga mencetak para jama'ah menjadi seorang pribadi muslim dan muslimah yang mandiri, berwawasan Islam yang luas, berakhlakul karimah dan berwirausaha serta mencintai Nabi Muhammad setelah para Sahabat, Habaib, 'Alim Ulama, dan Ustadz.

Media dakwah adalah sarana yang digunakan dalam menyampaikan pesan-pesan dakwah. Disebutkan Deddy Mulyana bahwa media bisa merujuk pada alat maupun bentuk pesan, baik verbail maupun non verbal, seperti cahaya dan suara. Saluran juga bisa merujuk pada cara penyajian, seperti tatap muka (langsung) atau lewat media, seperti surat kabar majalah, radio, telepon dan televisi. Sering pula disebut bahwa apa yang dikategorikan sebagai media juga disebut sebagai cara atau metode. Cara dakwah dengan menerangkan maupun menginformasikan, terutama meninformasikan lewat lisan misalnya, sering disebut dakwah bi al-lisan, karena menginformasikan dan menerangkannya dengan lisan. Jadi, terkadang menggunakan istilah memiliki konotasi sesuai maksud penggunaannya, terutama istilah-istilah yang memiliki makna samar dan beragam (Aripudin, 2011: 13). 
A. Ikrima, K. Diningrat, \& Rojudin

\section{Hubungan Kecintaan Jamaah Majelis Rasulullah Tambun Cibitung Cikarang dengan Dakwah Islam}

Hubungan kecintaan jamaah Majelis Rasulullah Tambun Cibitung Cikarang dengan dakwah Islam diketahui setelah melakukan penghitungan hasil kuisioner yang disebarkan kepada jamaah. Dari sepuluh item pertanyaan, rata-ratanya $(4,86+4,84+4,79+4,83+4,81+4,82+4,67$ $+4,75+4,54+4,45)=47,36: 10=4,736$. Angka ini termasuk ke dalam kualifikasi sangat tinggi, karena berada pada interval 4,20 - 5,00. Hal ini dapat menunjukkan bahwa kecintaan jama'ahnya dalam dakwah Islam sangat tinggi.

Proses penghitungan uji normalitas data variabel $\mathrm{X}$ berdasarkan hasil angket yang penulis sebarkan kepada 213 orang. Untuk mengetahui analisis tentang Pengaruh Dakwah Majelis Rasulullah (MRTCC) Hubungannya dengan Jama'ahnya didasarkan pada nilai total responden. Dan jika diurutkan kesamping dari skor terkecil sampai terbesar dapat disajikan sebagai berikut:

Tabel 1 : Distribusi Frekuensi Variabel X

\begin{tabular}{llllllll}
\hline No. & $\begin{array}{l}\text { Kelas } \\
\text { Interval }\end{array}$ & Fi & F/fkb & Xi & xi2 & Fixi & Fi (xi2) \\
\hline 1 & $38-40$ & 10 & 10 & 39,5 & 1560,25 & 395 & 15602,5 \\
2 & $41-42$ & 14 & 24 & 41,5 & 1722,25 & 581 & 24111,5 \\
3 & $43-44$ & 32 & 56 & 43,5 & 1892,25 & 1392 & 60552 \\
4 & $45-46$ & 41 & 97 & 45,5 & 2070,25 & 1865,5 & 84880,25 \\
5 & $47-48$ & 48 & 145 & 47,5 & 2256,25 & 2280 & 108300 \\
6 & $49-50$ & 68 & 213 & 49,5 & 2450,25 & 3366 & 166617 \\
& Jumlah & & 213 & & & 9879,5 & 460063,25 \\
\hline
\end{tabular}

Sumber Hasil Perhitungan Statistika

Tabel 2 : Distribusi Frekuensi Observasi dan ekspektasi Variabel X

\begin{tabular}{lllllllll}
\hline $\begin{array}{l}\text { Kelas } \\
\text { Interval }\end{array}$ & $\begin{array}{l}\text { Batas } \\
\text { Kelas }\end{array}$ & Zhitung & $Z_{\text {tabel }}$ & Li & Oi/fi & Ei/Li*N & Oi $-\mathrm{Ei}$ & $\frac{(O i-E i)^{2}}{E i}$ \\
\hline \multirow{2}{*}{$38-40$} & 37,5 & $-3,04$ & 0,4988 & & & & & \\
& 40,5 & $-2,01$ & 0,4778 & & & & & \\
\end{tabular}


Dakwah Majelis Rasulullah dan Kecintaan Jama'ah dalam Dakwah Islam

\begin{tabular}{|c|c|c|c|c|c|c|c|c|}
\hline \multirow[t]{2}{*}{$41-42$} & & & & 0,0712 & 14 & 15,1656 & $-1,1656$ & 0,089585 \\
\hline & 42,5 & $-1,32$ & 0,4066 & & & & & \\
\hline \multirow[t]{2}{*}{$43-44$} & & & & 0,1677 & 32 & 35,7201 & $-3,7201$ & 0,387432 \\
\hline & 44,5 & $-0,64$ & 0,2389 & & & & & \\
\hline \multirow[t]{2}{*}{$45-46$} & & & & 0,2229 & 41 & 47,4777 & $-6,4777$ & 0,883795 \\
\hline & 46,5 & 0.04 & 0,0160 & & & & & \\
\hline \multirow[t]{2}{*}{$47-48$} & & & & $-0,2482$ & 48 & 52,8666 & $-4,8666$ & 0,447991 \\
\hline & 48,5 & 0,72 & 0,2642 & & & & & \\
\hline \multirow[t]{2}{*}{$49-50$} & & & & 0,1565 & 68 & 33,3345 & 34,6655 & 36,0496 \\
\hline & 50,5 & 1,41 & 0,4207 & & & & & \\
\hline
\end{tabular}

Jumlah 44,687763

Sumber Hasil Perhitungan Statistika

Berdasarkan hasil hitungan, data ini diperoleh nilai chi kuadrat ( $\mathrm{X}_{\text {hitung }}^{2}$ ) sebesar 44,7 dan nilai chi kuadrat $\left(\mathrm{X}_{\text {tabel }}^{2}\right)$ sebesar 5,7. Maka dapat disimpulkan $X^{2}{ }_{\text {hitung }}>X_{\text {tabel, }}^{2}$ bahwa data variabel X berdistribusi Tidak Normal

Proses penghitungan uji normalitas data Variabel $\mathrm{Y}$ analisis ini dimaksudkan untuk mengetahaui skor rata-rata jawaban responden dari 213 orang dari Jama'ah Majelis Rasulullah Tambun Cibitung Cikarang Kabupaten Bekasi. 10 item soal angket untuk mengetahui kecintaan jama'ah terhadap dakwah Islam di Majelis Rasulullah Tambun Cibitung Cikarang Kabupaten Bekasi. Untuk mengetahui analisis didasarkan pada nilai total responden. Dan jika diurutkan kesamping dari skor terkecil sampai terbesar dapat disajikan sebagai berikut:

Tabel 3 : Distribusi Frekuensi Variabel Y

\begin{tabular}{lllllll}
\hline $\begin{array}{l}\text { Kelas } \\
\text { Interval }\end{array}$ & $\mathrm{Fi}$ & $\mathrm{F} / \mathrm{fkb}$ & $\mathrm{Xi}$ & $\mathrm{xi} 2$ & Fixi & $\mathrm{Fi}(\mathrm{xi} 2)$ \\
\hline $39-40$ & 10 & 10 & 39,5 & 1560,25 & 395 & 15602,5 \\
$41-42$ & 6 & 16 & 41,5 & 1722,25 & 581 & 24111,5 \\
$43-44$ & 16 & 32 & 43,5 & 1892,25 & 1392 & 60552 \\
$45-46$ & 38 & 70 & 45,5 & 2070,25 & 1865,5 & 84880,25 \\
$47-48$ & 41 & 111 & 47,5 & 2256,25 & 2280 & 108300 \\
$49-50$ & 102 & 213 & 49,5 & 2450,25 & 3366 & 166617 \\
Jumlah & & 213 & & & 9879,5 & 460063,25 \\
\hline
\end{tabular}

Sumber Hasil Perhitungan Statistika

Tabligh: Jurnal Komunikasi dan Penyiaran Islam Vol. 1 No. 2 (2016) 19-36 
Setelah mean, median, modus diketahui maka data Variabel $\mathrm{X}$ ini mempunyai kecenderugan ke arah POSITIF

Setelah ini tendensi sentral variabel diperoleh, tahap selanjutnya yaitu menguji dan menginterpretasikan kenormalitasan data, melalui langkahlangkah sebagai berikut:

Tabel 4 : Distribusi Frekuensi Observasi dan ekspektasi Variabel Y

\begin{tabular}{|c|c|c|c|c|c|c|c|c|}
\hline $\begin{array}{l}\text { Kelas } \\
\text { Interval }\end{array}$ & $\begin{array}{l}\text { Batas } \\
\text { Kelas }\end{array}$ & $Z_{\text {hitung }}$ & $\mathrm{Z}_{\text {tabel }}$ & $\mathrm{Li}$ & $\mathrm{Oi} / \mathrm{fi}$ & $\mathrm{Ei} / \mathrm{Li}^{*} \mathrm{~N}$ & $\mathrm{Oi}-\mathrm{Ei}$ & $\frac{(O i-E i)^{2}}{E i}$ \\
\hline & 38,5 & $-2,69$ & 0,4964 & & & & & \\
\hline \multirow[t]{2}{*}{$39-40$} & & & & 0,0186 & 10 & 3,9618 & 6,0382 & 9,202852 \\
\hline & 40,5 & $-2,01$ & 0,4778 & & & & & \\
\hline \multirow{2}{*}{$41-42$} & & & & 0,0712 & 6 & 15,1656 & $-9,1656$ & 5,539393 \\
\hline & 42,5 & $-1,32$ & 0,4066 & & & & & \\
\hline \multirow[t]{2}{*}{$43-44$} & & & & 0,1677 & 16 & 35,7201 & $-19,7201$ & 10,8879 \\
\hline & 44,5 & $-0,64$ & 0,2389 & & & & & \\
\hline \multirow[t]{2}{*}{$45-46$} & & & & 0,2229 & 38 & 47,4777 & $-9,4777$ & 1,891978 \\
\hline & 46,5 & 0.04 & 0,0160 & & & & & \\
\hline \multirow[t]{2}{*}{$47-48$} & & & & $-0,2482$ & 41 & 52,8666 & $-11,8666$ & 2,663613 \\
\hline & 48,5 & 0,72 & 0,2642 & & & & & \\
\hline \multirow[t]{2}{*}{$49-50$} & & & & 0,1565 & 102 & 33,3345 & 68,6655 & 141,4435 \\
\hline & 50,5 & 1,41 & 0,4207 & & & & & \\
\hline
\end{tabular}

$\frac{\text { Jumlah } 171,629236}{\text { Sumber Hasil Perhitungan Statistika }}$

Berdasarkan hasil hitungan, data ini diperoleh nilai chi kuadrat $\left(\mathrm{X}_{\text {hitung }}^{2}\right)$ sebesar 171,7 dan nilai chi kuadrat $\left(\mathrm{X}_{\text {tabel }}^{2}\right)$ sebesar 5,7. Maka dapat disimpulkan $X_{\text {hitung }}^{2}>X_{\text {tabel, }}^{2}$, bahwa data variabel $\mathrm{X}$ berdistribusi Tidak Normal.

Setelah dilihat dari tabel, ternyata 0,95(211) tercantum. Berdasarkan perhitungan diatas, $t_{\text {hitung }}=10,35$ sedangkan $t_{\text {tabel }}=20,04$ dengan melihat pernyataan tersebut, maka $t_{\text {hitung }}<\mathrm{t}_{\text {tabel }}$ yaitu $10,35<20,04$. Hal tersebut disebabkan karena antatra kedua variabel mempunyai hubungan yang signifikan. Dengan demikian dapat ditarik kesimpulan terhadap hubungan 
yang signifikan antara Dakwah Majelis Rasulullah dengan Kecintaan Jama'ahnya dalam Dakwah Islam, ada hubungan satu sama lain karena saling membutuhkan. Dengan kata lain Ha diterima dan Ho ditolak.

Berdasarkan penghitungan diatas, dapat disimpulkan bahwa Pengaruh Dakwah Majelis Rasulullah terhadap Kecintaan Jama'ahnya di Majelis Rasulullah Tambun Cibitung Cikarag sebesar 40\%. Sehingga diinterprestasikan bahwa tidak hanya dengan kecintaan saja namun masih ada 60\% dipengaruhi oleh faktor lain.

Dari penjelasan di atas maka dalam penelitian ini terdapat dua variabel yaitu independen (variabel X) dan dependent (variabel Y). Pengaruh Dakwah Majelis Rasulullah sebagai variabel independen (variabel X) dan Kecintaan Jamaahnya sebagai variabel dependent (variabel Y) secara asumsi teoritik yang telah dijelaskan di atas dapat dikatakan bahwa kedua variabel tersebut mempunyai hubungan erat. Ketika kedua variabel itu memiliki hubungan erat maka akan terjadi perubahan sikap dan pola perilaku, menurut Soekanto (2007: 263) perubahan-perubahan pada lembagalembaga kemasyarakatan di dalam suatu masyarakat, yang memengaruhi sistem sosialnya, termasuk di dalamnya nilai-nilai, sikap, dan pola perilaku di antara kelompok-kelompok dalam masyarakat.

\section{PENUTUP}

Berdasarkan hasil penelitian dan pembahasan mengenai Pengaruh Dakwah Majelis Rasulullah Terhadap Kecintaan Jama'ahnya Dalam Dakwah Islam (Majelis Rasulullah Tambun Cibitung Cikarang Kabupaten Bekasi) dapat disimpulkan sebagai berikut : Kegiatan MRTCC mingguan, bulanan dan tahunan. Kegiatan mingguan dilaksanakan pada malam selasa dan malam kamis dan malam minggu yaitu jadwal mingguan di Majelis Rasulullah pusat. Untuk kegiatan mingguan MR pusat difokuskan pada malem selasa dan malem minggu saja karena lokasi yang jauh.

Ada pula kegiatan khusus perempuan yaitu pengajian nisa pada malem minggu setiap bada asar dan diadakan pula pelatihan hadroh dan kewirausahaan. Ada juga kegiatan RMS (Ratib Maulid Sulamuttaufiq) yaitu Pengajian fiqih yang mengkaji kitab sulam taufiq yang dipimpin oleh Ustad. Faiz Nawawi yang dilaksanakan pada dua minggu sekali. Dan pengajian kitab Uquddulluzain. Untuk kegiatan bulanan adalah kegiatan kopdar yaitu forum silaturahmi semua pengurus dan jamaah mrtcc kab bekasi. Tempatnya diluar sekretariat karena jamaah ingin sekali diwilayahnya baik 
itu Masjid, Mushola, dan Rumah kediaman mereka pribadi. Kopdar itu isinya, pengaiian pembacaan ratib, ad-dhiyaul lami dan tausiyah habib muhamad ali al kaff, kegiatan di minggu pertama setiap bulannya. Untuk kegiatan tahunan yaitu tabligh akbar atau peringatan hari besar Islam, untuk tempatnya bergiliran tempatnya diatur oleh pengurus. Untuk kegiatan lainnya yaitu bakti sosial kalo ada musibah, ziarah, ziarah kubro, berbagi ta'jil di bulan romadhon, halal bi halal atau bergabung atau bekerja sama dengan Majlis dzikir lainnya, dan kegiatan lainnya.

MRTCC ini melakukan dakwah juga dengan berdagang atau berwirausaha karena mengikuti jejak Nabi Muhammad yang mensyiarkan agama melalui perdagangan. Selain itu juga mencetak para jama'ah menjadi seorang pribadi muslim dan muslimah yang mandiri, berwawasan Islam yang luas, berakhlakul karimah dan berwirausaha serta mencintai Nabi Muhammad setelah para Sahabat, Habaib, 'Alim Ulama, dan Ustadz. Motivasi yang terkumpul dari kisah-kisah para sahabat mencintai Rasulullah dan apa yang dilakukan oleh Rasulullah.

Hasil penelitian menunjukkan bahwa: Pengaruh Dakwah Majelis Rasulullah memperoleh kualifikasi tinggi. Hal ini di tunjukkan oleh rata-rata nilai jawaban jumlah variabel X mencapai 46,4. Setelah dibagi jumlah item diperoleh angka 4,64, jika ditafsirkan angka tersebut berada diantara interval 4,20 - 5,00. Kecintaan Jama'ah dalam Dakwah Islam termasuk dalam kualifikasi tinggi. Hal ini ditunjukkan oleh nilai rata-rata jawaban mereka terhadap 10 item angket yang diajukan, mencapai nilai rata-rata sebesar 47,36. Setelah dibagi oleh jumlah item diperoleh angka 4,736 jika ditafsirkan angka tersebut berada diantara interval 4,20 - 5,00 termasuk kualifikasi tinggi. Demikian dapat disimpulkan bahwa Kecintaan Jama'ahnya dalam Dakwah Islam sangat tinggi. Pengaruh Majelis Rasulullah, koefisiennya 1,0 dengan kadar pengaruhnya $40 \%$ hal tersebut dapat disimpulkan bahwa masih ada sekitar $60 \%$ dari faktor lain yang turut mempengaruhi Hubungannya Terhadap Kecintaan Jama'ahnya dalam Dakwah Islam.

Adapun faktor tersebut adalah adanya kemauan dalam diri sendiri ataupun keinginan dan motivasi diri yang sangat tinggi, melakukan dakwah juga dengan berdagang atau berwirausaha karena mengikuti jejak Nabi Muhammad yang mensyiarkan agama melalui perdagangan. Selain itu juga mencetak para jama'ah menjadi seorang pribadi muslim dan muslimah yang mandiri, berwawasan Islam yang luas, berakhlakul karimah dan berwirausaha serta mencintai Nabi Muhammad setelah para Sahabat, Habaib, 'Alim Ulama, dan Ustadz. 
Berdasarkan kesimpulan tersebut maka penelitian ini memberikan rekomendasi yang pertama kepada civitas Akademika Jurusan Komunikasi dan Penyiaran Islam fakultas Dakwah dan Komunikasi UIN Sunan Gunung Djati Bandung untuk dapat mengembangkan penelitian tentang dakwah di majlis-majlis atau komunitas dakwah. Dan khususnya kecintaan dakwah para jama'ah Majelis Rasulullah dalm penelitian ini disarankan untuk dijadikan sumber referensi dalam perkembangan dakwah pada ranah khitabah.

Rekomendasi yang kedua diberikan kepada para praktisi dakwah. Penelitian ini sangat direkomendasikan untuk dijadikan sumber wawasan, referensi bahkan untuk dijadikan sebagai pedoman para praktisi dakwah yang melakukan dakwah melalui majlis-majlis ilmu atau komunitas dakwah.

Rekomendasi selanjutnya ditujukan kepada aktivis atau penggerak Majlis Rasulullah Tambun Cibitung Cikarang untuk terus menciptakan metode baru dalam berdakwah agar para jama'ah selalu mencintai dakwah Islam dan memperluas wawasan ilmu pengetahuan keIslamannya.

Kegiatan dakwah yang berlangsung pada Majelis Rasulullab Tambun Cibitung Cikarang merupakan salah satu pengemasan dari kegiatan dakwah yang masih konvesional ke dalam kegiatan dakwah yang dapat memanfaatkan media tempat atau komunitas. Oleh sebab itu penulis menyarankan kepada komunikator, Da'i atau pendakwah untuk bisa lebih kreatif untuk menentukan metode dakwah dalam menyampaikan dakwahnya agar apa yang disampaikan dapat dimengerti dan dipahami oleh mad'u.

\section{DAFTAR PUSTAKA}

Abdul, Aziz, Ahmad. (2009) Fiqh Cinta. Pustaka Indah. Bandung. Aripudin, Acep (2007) Dakwah Antar Budaya. Remaja Rosdakarya.

A.S., Enjang \& Aliyudin. (2009). Dasar-Dasar Ilmu Dakwah. Bandung:

Widya Padjajaran.

Aziz, M. A. (2004). Ilmu Dakwah. Jakarta: Prenada Media.

Departemen Agama RI. (2009). Al-Qur'an Dan Terjemahnya. Kiara

Condong. Bandung: PT. Syamil Qur'an Yasmina.

Ghazali, Imam. (tt) Rahasia Ketajaman Mata Hati (Mukasyafatul Qulub.). Surabaya,Terbit Terang.

Ghazali, Imam. (2014). Kitab Cinta dan Rindu. Jakarta Selatan:. Khatulistiwa Press.

Majelis Rasulullah, Dewan guru (2014), Biografi Majelis Rasulullah, diakses 
A. Ikrima, K. Diningrat, \& Rojudin

pada tanggal 26 April 2016, dari

https://www.majelisrasulullah.org/biografi-majelis-rasulullah/

Saipul Ma’arif, Bambang. (2016). Kisah Dua Mujabid Dakwah dari Bandung (kang Jalal dan $A a$ Gym), Bandung: Nuansa.

Soekanto. (2007). Sosiologi Suatu Pengantar. Jakarta: PT. Raja Grafindo.

RS.Syamsudin.(2009). Strategi dan Etika Dakwah Rasulullab SAW dalam Ilmu

Dakwah: Academic Journal for Homiletic Studies, 4(14), 113. 